\section{Case Reports in Neurology}

Case Rep Neurol 2020;12:270-275

DOI: 10.1159/000508357
Published online: September 10, 2020

(c) 2020 The Author(s)

Published by S. Karger AG, Basel www.karger.com/crn

This article is licensed under the Creative Commons Attribution-NonCommercial 4.0 International License (CC BY-NC) (http://www.karger.com/Services/OpenAccessLicense). Usage and distribution for commercial purposes requires written permission.

\title{
The Effectiveness of Perampanel for Myoclonic Seizures in Down Syndrome with Isodicentric Chromosome 21
}

\author{
Koji Obara ${ }^{\mathrm{a}}$ Tsuyoshi Imota $^{\mathrm{a}}$ Shigeo Mamiya $^{\mathrm{b}} \quad$ Itaru Toyoshima $^{\mathrm{a}}$ \\ aDepartment of Neurology, National Hospital Organization, Akita National Hospital, \\ Yurihonjo, Japan; 'bepartment of Internal Medicine, National Hospital Organization, Akita \\ National Hospital, Yurihonjo, Japan
}

\section{Keywords}

Down syndrome · Epilepsy · Isodicentric chromosome $21 \cdot$ Myoclonus $\cdot$ Perampanel

\begin{abstract}
Epileptic seizures are common in the elderly Down syndrome population. We encountered a patient with Down syndrome in whom karyotyping showed the rare isodicentric chromosome 21 and who suffered from myoclonic seizures. A 52-year-old woman with Down syndrome experienced sudden onset of drowsiness and frequent myoclonic jerks in the upper body. Video-EEG recordings demonstrated generalized polyspike-wave discharges consistent with myoclonic jerks, which were exacerbated by photo-stimulation. Her myoclonus completely resolved with perampanel administration. Perampanel was effective for myoclonic seizures in our patient. We suggest that perampanel is an option as first-line therapy for epilepsy and myoclonus in elderly Down syndrome patients.

(c) 2020 The Author(s)

Published by S. Karger AG, Basel
\end{abstract}

\section{Introduction}

The increased longevity of patients with Down syndrome (DS) has resulted in neurologists encountering epilepsy and cognitive decline (CD) more frequently [1-3]. Epilepsy mostly 


\section{Case Reports in Neurology}

Case Rep Neurol 2020;12:270-275

DOI: 10.1159/000508357

(c) 2020 The Author(s). Published by S. Karger AG, Basel www.karger.com/crn

Obara et al.: The Effectiveness of Perampanel for Myoclonic Seizures in Down Syndrome with Isodicentric Chromosome 21

begins within a year after onset of $\mathrm{CD}[2,3]$. Epilepsy usually involves myoclonic jerks and forms generalized tonic-colonic seizures [2, 3]. Over months and years of progression, myoclonic seizures are replaced by nonepileptic myoclonus, and photosensitivity develops $[2,3]$. We encountered a case of DS with rare karyotyping, i.e., isodicentric chromosome 21, in which myoclonic seizures first appeared 12 years after onset of $\mathrm{CD}$. The patient responded well to low-dose perampanel monotherapy.

\section{Case Report}

A 52-year-old woman without a history of any seizures or myoclonus was referred to our neurology department with continuous jerking movement in her upper body that began the day before. She was diagnosed with DS at 9 months of age. She was able to run, dance, and sing, and her daily activities were mostly independent. From the age of 40 years, her cognitive function gradually declined, resulting in progressive loss of autonomy. At the age of 50 years, she was admitted to our hospital. At the time, although she could not stand and walk, she spoke cheerfully and participated in play activities every day. While in our department, on general physical examination, her height and weight were $146 \mathrm{~cm}$ and $47 \mathrm{~kg}$, respectively. Blood pressure was $118 / 60 \mathrm{~mm} \mathrm{Hg}$, heart rate was 117 beats/min, temperature was $36.9^{\circ} \mathrm{C}$, and oxygen saturation was $97 \%$ on room air. A general examination revealed morphological features of DS including a small chin, slanted eyes, a flat nasal bridge, a single crease of the palm, and a protruding tongue. On neurological examination, she was drowsy and exhibited mutism. She did not follow any orders, and voluntarily moved her eyes, mouth, head, and extremities. All the while, myoclonic jerks appeared continuously once every 3-5 s in her upper body. Her lower limbs showed mild atrophy. No fasciculation or myokymia was found anywhere. Her muscle tone was slightly high with paratonia of the bilateral upper limbs. She could not walk and stand even with assistance, and she needed a trunk belt to sustain a sitting position in the wheelchair. Deep tendon reflexes, including the biceps, triceps, patellar tendon, and Achilles tendon reflexes, showed hyperreflexia in both upper and lower limbs. Babinski signs were negative on both feet. Laboratory testing revealed sodium, $143 \mathrm{mmol} / \mathrm{L}$; potassium, 3.3 $\mathrm{mmol} / \mathrm{L}$; chloride, $106 \mathrm{mmol} / \mathrm{L}$; glucose, $120 \mathrm{mg} / \mathrm{dL}$; creatinine, $0.48 \mathrm{mg} / \mathrm{dL}$; calcium, 8.0 $\mathrm{mg} / \mathrm{dL}$; serum albumin, $3.1 \mathrm{~g} / \mathrm{dL}$; and ammonia, $18 \mu \mathrm{g} / \mathrm{dL}$. Thyroid function and thiamine and vitamin $B_{12}$ levels were within normal limits. Video-EEG recordings showed generalized continuous slowing, generalized intermittent rhythmic sharp waves, and generalized polyspikewave complexes consistent with myoclonic jerks on the monitor (Fig. 1a). Intermittent photostimulation within 9-24 Hz induced polyspike-wave complexes and myoclonic jerks (Fig. 1b). Brain MRI showed severe cortical atrophy and ventricle enlargement (Fig. 2a). On diffusionweighted image, no high-intensity lesion was found (Fig. 2b). Single-photon emission computed tomography (SPECT) revealed a significant hypoperfusion around the Sylvian fissure, parietal region, and cingulate gyrus (Fig. 2c). Chromosome analysis detected a female karyotype denoted by 46,XX,idic(21)(q22.3) with a normal chromosome 21 and an isodicentric chromosome 21, which had 2 copies of the long arm of chromosome 21 with inverted fusion at the q22.3 band (Fig. 2d). She was started on perampanel at $2 \mathrm{mg} /$ day. A week later, blood concentration of perampanel was $176 \mathrm{ng} / \mathrm{mL}$. Her myoclonus completely resolved, and she returned to her baseline mentation. On follow-up EEG, myoclonic discharges disappeared and were not evoked even by photo-stimulation. 


\section{Case Reports in Neurology}

Obara et al.: The Effectiveness of Perampanel for Myoclonic Seizures in Down Syndrome with Isodicentric Chromosome 21

\section{Discussion/Conclusion}

We found 2 important clinical issues. An elderly patient with DS had isodicentric chromosome 21 with myoclonic seizures first appearing 12 years after onset of CD. Low-dose perampanel monotherapy was remarkably effective for her seizures.

About half of DS patients over the age of 50 years show epilepsy, which is mostly preceded by CD [2,3]. Epilepsy associated with DS can be divided into 3 stages during its course [3]. Stage I: At onset of CD, diffuse EEG abnormalities during sleep and cerebral atrophy are shown. Stage II: Within a year after onset of CD, generalized tonic-clonic seizures usually occur with epileptic myoclonic jerks of the face and hands upon awakening. Stage III: Over months and years of progression, myoclonic seizures are replaced with nonepileptic myoclonus, and severe dementia and photosensitivity on EEG develop. In our patient, it was uncommon that myoclonic seizures suddenly appeared 12 years after onset of CD.

Over $90 \%$ of DS individuals are identified as free trisomy $21[4,5]$. The isodicentric chromosome 21 [46,XX,idic(21)(q22.3)] shown in our patient is a rare chromosomal rearrangement that may result in DS [4]. The rearrangement has 2 copies of the long arm of chromosome 21 with inverted fusion at the q22.3 band, which results in partial monosomy due to 21q22.3 terminal deletion [4]. Cases with isodicentric chromosome 21 reported previously did not have any differences in phenotype from common trisomy $21[4,6]$. Therefore, it was not clear whether this isodicentric chromosome 21 contributed to the uncommon clinical course in our patient with a long interval between onset of CD and epilepsy.

A low dose of perampanel was remarkably effective for myoclonic seizures in our patient. Perampanel, a third-generation anti-epileptic drug, is a noncompetitive alpha-amino-3-hydroxy-5-methyl-4-isoxazolepropionic acid (AMPA) receptor antagonist that is highly effective as an adjuvant therapy in patients with generalized and focal epilepsy [7]. Furthermore, perampanel was newly approved as monotherapy for focal epilepsy in Japan in January 2020 [8]. Recently, the efficacy of low-dose perampanel has been reported in refractory myoclonus in epilepsy patients $[9,10]$. Perampanel has a good safety profile and is well tolerated, and therapeutic drug monitoring is considered useful since the dose correlates linearly with effect and adverse events [11]. However, a reliable therapeutic range for the plasma concentration of perampanel has not been established because individual reference ranges vary widely [11]. According to previously reported data [12], in 92 adult patients at steady state, the mean overall plasma concentration of perampanel was $323.5 \mathrm{ng} / \mathrm{mL}$. The corresponding mean dose was $7.5 \mathrm{mg}$ (range 2-12 mg). On the other hand, in our hospital, the plasma concentration of patients taking perampanel was generally around $1,000 \mathrm{ng} / \mathrm{mL}$ [unpubl. data]. Thus, our patient was able to achieve resolution of seizures with a lower dose and lower plasma concentration of perampanel.

In conclusion, it was noteworthy that low-dose perampanel monotherapy was effective for myoclonic seizures in our patient with isodicentric chromosome 21. If elderly DS patients show epilepsy and myoclonus, even at an advanced stage, we suggest perampanel as an option for first-line therapy. Further data should be gathered regarding the clinical picture of DS with rare karyotyping and administration of perampanel for DS.

\section{Statement of Ethics}

The parent of the patient provided both oral and written informed consent for the publishing of this report (including publication of images). 


\section{Case Reports in Neurology}

\begin{tabular}{l|l} 
Case Rep Neurol 2020;12:270-275 \\
\hline DOI: 10.1159/000508357 & $\begin{array}{l}\text { ( ) 2020 The Author(s). Published by S. Karger AG, Basel } \\
\text { www.karger.com/crn }\end{array}$ \\
\hline
\end{tabular}

Obara et al.: The Effectiveness of Perampanel for Myoclonic Seizures in Down Syndrome with Isodicentric Chromosome 21

\section{Conflict of Interest Statement}

The authors have no conflicts of interest to declare.

\section{Funding Sources}

The authors did not receive any external funding.

\section{Author Contributions}

Koji Obara was the patient's primary neurologist and drafted the manuscript. Shigeo Mamiya was the patient's primary neurologist and physician. Tsuyoshi Imota performed the electrophysiological examinations for the patient. Itaru Toyoshima revised the manuscript and edited the paper.

\section{References}

1 Bayen E, Possin KL, Chen Y, Cleret de Langavant L, Yaffe K. Prevalence of Aging, Dementia, and Multimorbidity in Older Adults with Down Syndrome. JAMA Neurol. 2018 Nov;75(11):1399-406.

2 De Simone R, Puig XS, Gélisse P, Crespel A, Genton P. Senile myoclonic epilepsy: delineation of a common condition associated with Alzheimer's disease in Down syndrome. Seizure. 2010 Sep;19(7):383-9.

3 d'Orsi G, Specchio LM; Apulian Study Group on Senile Myoclonic Epilepsy. Progressive myoclonus epilepsy in Down syndrome patients with dementia. J Neurol. 2014 Aug;261(8):1584-97.

4 Putra M, Surti U, Hu J, Steele D, Clemens M, Saller DN, et al. Beyond Down syndrome phenotype: paternally derived isodicentric chromosome 21 with partial monosomy 21q22.3. Am J Med Genet A. 2017 Dec;173(12):3153-7.

5 Flores-Ramírez F, Palacios-Guerrero C, García-Delgado C, Morales-Jiménez AB, Arias-Villegas CM, Cervantes A, et al. Cytogenetic profile in 1,921 cases of trisomy 21 syndrome. Arch Med Res. 2015 Aug;46(6):484-9.

6 Egashira M, Kondoh T, Kawara H, Motomura H, Tagawa M, Harada N, et al. Mirror duplication of chromosome 21 with complete phenotype of Down syndrome. Pediatr Int. 2008 Aug;50(4):597-9.

7 Potschka H, Trinka E. Perampanel: does it have broad-spectrum potential? Epilepsia. 2019 Mar;60 Suppl $1: 22-36$.

8 Eisai [Internet]. Approval of antiepileptic drug FYCOMPA® in Japan for monotherapy and pediatric indications for partial-onset seizure, as well as a new formulation. [cited 2020 Jan 23]. Available from: https://www.eisai.co.jp/news/2020/pdf/news202004pdf.pdf

9 Oi K, Neshige S, Hitomi T, Kobayashi K, Tojima M, Matsuhashi M, et al. Low-dose perampanel improves refractory cortical myoclonus by the dispersed and suppressed paroxysmal depolarization shifts in the sensorimotor cortex. Clin Neurophysiol. 2019 Oct;130(10):1804-12.

10 Iijima M, Oguni H, Kobayashi M, Kitagawa K. Perampanel improved intractable myoclonus in two patients with myoclonus epilepsy. eNeurologicalSci. 2019 Nov;17:100215.

11 Reimers A, Berg JA, Burns ML, Brodtkorb E, Johannessen SI, Johannessen Landmark C. Reference ranges for antiepileptic drugs revisited: a practical approach to establish national guidelines. Drug Des Devel Ther. 2018 Feb;12:271-80.

12 Steinhoff BJ, Hübers E, Kurth C, Jürges Kehl-Kork U. Plasma concentration and clinical effects of perampanel - The Kork experience. Seizure. 2019 Apr;67:18-22. 


\section{Case Reports in Neurology}

\begin{tabular}{l|l}
\hline Case Rep Neurol 2020;12:270-275 \\
\hline DOI: 10.1159/000508357 & $\begin{array}{l}\text { c 2020 The Author(s). Published by S. Karger AG, Basel } \\
\text { www.karger.com/crn }\end{array}$ \\
\hline
\end{tabular}

Obara et al.: The Effectiveness of Perampanel for Myoclonic Seizures in Down Syndrome with Isodicentric Chromosome 21

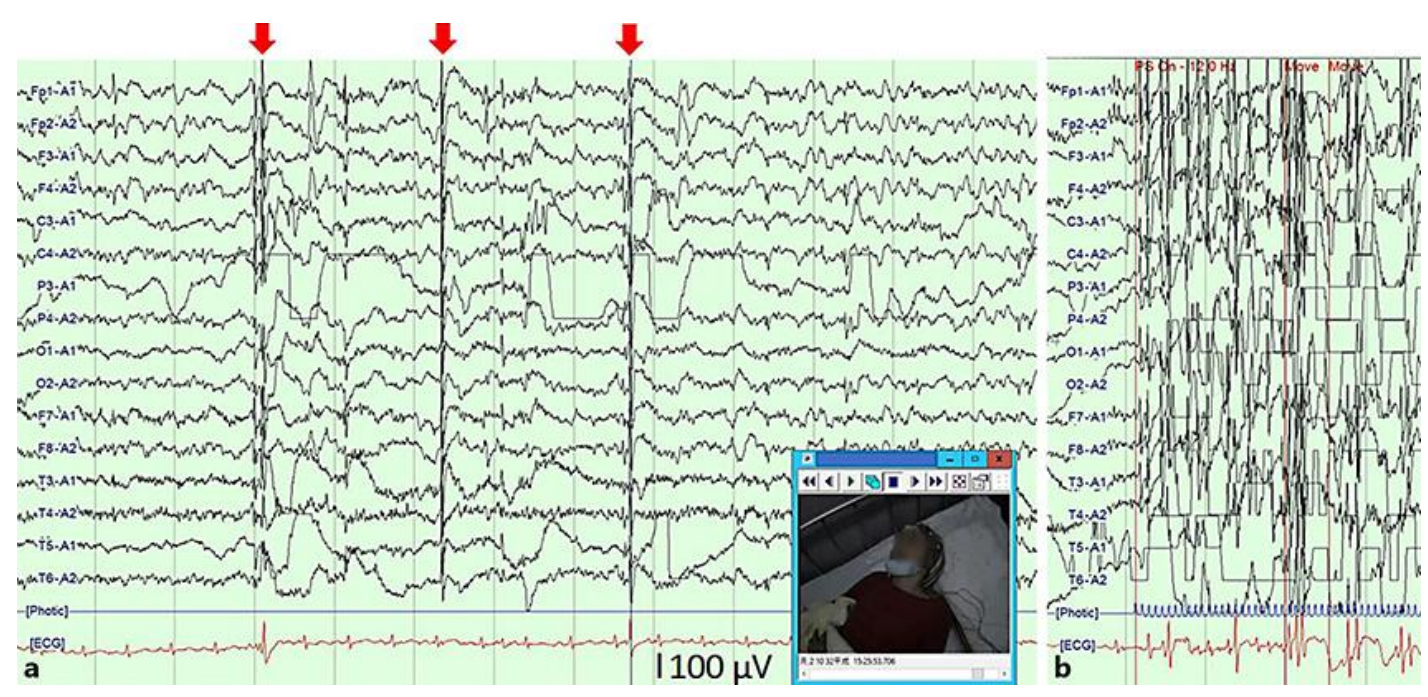

Fig. 1. a Video-EEG taken at the referral day shows generalized polyspike-wave complexes (arrows) consistent with myoclonic jerks on the monitor. b Intermittent photo-stimulation at $12 \mathrm{~Hz}$ induces polyspikewave complexes and myoclonic jerks. 


\section{Case Reports in Neurology}

\begin{tabular}{l|l}
\hline Case Rep Neurol 2020;12:270-275 \\
\hline DOI: 10.1159/000508357 & $\begin{array}{l}\text { @ 2020 The Author(s). Published by S. Karger AG, Basel } \\
\text { www.karger.com/crn }\end{array}$ \\
\hline
\end{tabular}

Obara et al: The Effectiveness of Perampanel for Myoclonic Seizures in Down Syndrome with Isodicentric Chromosome 21
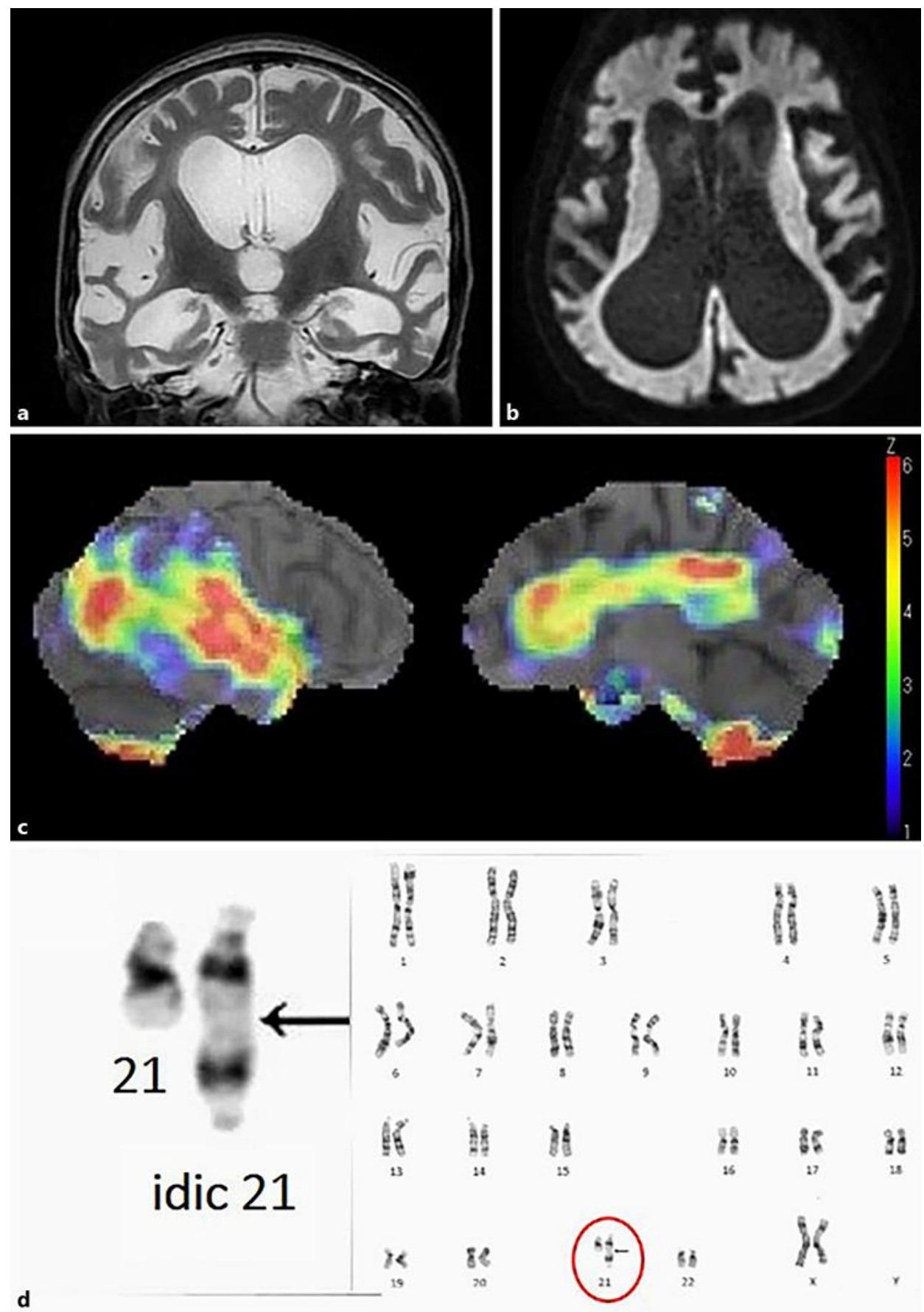

d

Fig. 2. a Brain MRI shows severe cortical atrophy and ventricle enlargement. b On diffusion-weighted image, no high-intensity lesion is found. c Single-photon emission computed tomography reveals a significant hypoperfusion around the Sylvian fissure, parietal region, and cingulate gyrus. $\mathbf{d}$ Chromosome analysis detects a female karyotype denoted by 46,XX,idic(21)(q22.3) with a normal chromosome 21 and an isodicentric chromosome 21. idic, isodicentric chromosome. 